\title{
A Research on Concentration and Distribution of Airborne Particulate Matter in Kuantan City
}

\author{
Putri Shazlia Rosman, Mohd Armi Abu Samah, Kamaruzzaman Yunus
}

\begin{abstract}
The development of Kuantan city had caused a great emission of particulate matter concentration to the Kuantan atmospheric. The airborne of particulate matter may causes immediate and long-term impacts on human health as it enters the lung through the respiratory tract. The larger particles more than 10um aerodynamic diameter can found in soot or smoke. In this study, the concentration of particulate matter (PM10) in the ambient air of Kuantan city was investigated using two continues monitoring station by the Department of Environment. The PM 10 data were taken for 15 years of study from year 2001-2016. Two (2) location of the continues monitoring station were used in the study where one in Indera Mahkota, Kuantan and another was in Balok Baru, Kuantan. In the study, the highest PM10 concentration was in year 2013 with $234.31 \mathrm{ug} / \mathrm{m3}$ and the second highest in year 2015 with $271.62 \mathrm{ug} / \mathrm{m} 3$ for station 1. While, for station 2 the highest PM10 concentration were in year 2013 with $349.7 \mathrm{ug} / \mathrm{m} 3$ and the second highest in year 2015 with $328.46 \mathrm{ug} / \mathrm{m} 3$ respectively. The pattern distribution showed that the PM10 concentration between year 2013 to 2015 were absolutely outrages which was more than $300 \mathrm{ug} / \mathrm{m} 3$ was release in the atmospheric. The sources emission factor in this study can be from various sources and trans-boundary events may also be possible to cause the PM10 concentration disperse in Kuantan.
\end{abstract}

Index Terms:- Aerodynamic, atmospheric, emission, monitoring, pattern.

\section{INTRODUCTION}

Kuantan is a capital state of Pahang that still maintain it natural environment. In Kuantan district, there are waterfalls, seas, hills and many ecotourism places like Panorama Hills, Bukit Pelindung, Rainbow Waterfall and Chempedak Beach that offers attraction to many tourists to come and explore here. Despite, maintaining its beautiful nature, the needs of development to achieve sustainable city and increased economic growth for people of Kuantan, many constructions of infrastructure were done. Many shopping malls such as East Coast Mall, Kuantan City Mall, Berjaya Mall and Kuantan Parade come heaven place for being carried by the local authority to bring up Kuantan city as the best city to be stay in the East Coast State. Despite that to improve Kuantan city to become more lively, attractive urban center and high harmonious the quality of life style citizen that live here.

However, the air pollution from the development during construction to the turn the view of the city become cause

Revised Manuscript Received on July 10, 2019.

Putri Shazlia Rosman, Kulliyyah of Sciences, International Islamic University Malaysia, Indera Mahkota, Kuantan, Pahang, Malaysia..

Mohd Armi Abu Samah, Kulliyyah of Sciences, International Islamic University Malaysia, Indera Mahkota, Kuantan, Pahang, Malaysia.

Kamaruzzaman Yunus, Kulliyyah of Sciences, International Islamic University Malaysia, Indera Mahkota, Kuantan, Pahang, Malaysia. shoppers that visited Kuantan. Therefore, more development

serious issues to Kuantan citizen. In this study. We will understand the pattern distribution of PM10 since 2001 until 2016 the development of the Kuantan City. Many sources factor of pollution may contribute to the emission of the particulate matter. But, most of the emission particulate matter will be in short time period and will not last longer. These is due to the time frame of the construction activities take part. Other emission could cause from other such as mobile sources (car and lorry) or from different industrial emission. The unplanned and uncontrolled development of industrial premises could lead to higher emission [1].

\section{A. Particulate Matter (PM10)}

Particulate matter is a physical classification of particulates that found in soot, smoke, dust, dirty and liquid droplet. Particulate matter is a mixture of particulates from different composition, properties, sizes, and sources [2], [3]. Due to the mixture of aqueous and solid particulate, particulate matter can enter the atmosphere by natural and anthropogenic pathways [3]. The activities such as process heaters, vehicle exhaust, large boilers and incinerators from industrial combustion produce particulate matter. Particulate matter can be emitting directly into the air from stone crushing, wood burnings, unpaved roads, construction sites and factories. The sizes of PM10 are smaller than 10 micrometers in diameter but larger than 2.5 micrometers.

PM10 was recorded as one of the air pollutants concentration limits in New Malaysia Ambient Air Quality Standard. New Malaysia Ambient Air Quality Standard is a new standard to replace the Malaysia Ambient Air Quality Guidelines that has been used since 1989. In the new standard there are three (3) interim targets set for PM10 that are IT-1 until year 2015, IT-2 until year 2018 and the ambient air quality standard will be full implementation on year 2020. Each concentration for the interim target is different according to the year target. For IT-1 (2015) for averaging time for 1 year is $50 \mathrm{ug} / \mathrm{m}^{3}$ and 24 hours is 150 $\mathrm{ug} / \mathrm{m}^{3}$, for IT-2 (2018) for 1 year $45 \mathrm{ug} / \mathrm{m}^{3}$ and 24 hours is $120 \mathrm{ug} / \mathrm{m}^{3}$ and for year 2020 for 1 year is $40 \mathrm{ug} / \mathrm{m}^{3}$ and 24 hours is $100 \mathrm{ug} / \mathrm{m}^{3}$.

According to the previous studies the best indicator for the ambient air pollution is the PM [4]. The dangerous of PM10 could cause respiratory health risk through inhalation if it deposited at the thorax (bronchial, traces and alveolar regions) pose greater risk [5]. Particulate matter can cause serious health problem and it can also cause morbidity and mortality to human being [6], [7]. 


\section{A RESEARCH ON CONCENTRATION AND DISTRIBUTION OF AIRBORNE PARTICULATE MATTER IN KUANTAN CITY}

\section{METHODOLOGY}

\section{A. Study Design}

The study strategy was using the ambient PM to produce pattern distribution of PM within 15 year of data. From the PM distribution, we will determine the status of development that occurred within 15 years and the radius of distribution the PM. The development of the study involves the following stages: (1) literature review; (2) secondary data from the DOE; (3) analysis the data and (4) distribution of data.

\section{B. Data Sources}

Data distribution of PM10 were derived from Department of Environment Malaysia (DOE) that have its continuous air quality monitoring (CAQM) station to capture the ambient PM measurement. The PM10 data were from year 2001 until 2016 with two continuous monitoring station involved in Kuantan. The are several parameters measured by the CAQM other than PM10 such as Nitrogen Oxides, Carbon Monoxide, Ozone, Sulphur Dioxide, Hydrocarbon and UV. But in this study only PM10 was used. In this study, PM10 was the only parameter used in this study.

\section{Selection of Monitoring Station}

The study performed using 2 monitoring station that available in Kuantan area. The first monitoring station located at Sekolah Kebangsaan Indera Mahkota and second station was in Sekolah Kebangsaan Balok Baru. The location of the continuous air monitoring station as Fig. 1.

Indera Mahkota is a township that was open in year 1983 that have several function of administration government's complexes, commercial, educational institutions and residential area. The Palace of Istana Abdul Aziz also located in this area. Located 4 kilometers away from the northeast of Kuantan Town and about 38 kilometers away from the historical tin mining town of Sungai Lembing. It became as the main road for road user to enter East Coast Expressway via Kuantan Interchange. Indera Mahkota have its recreational area knowns as Taman Bandar for relaxing and pleasure for people who a needs moment away from the buzzing and stressful of city [8].

Balok Baru is village area that located about 37 kilometers from Kuantan Town. The area adjacent to the Pantai Balok, makes people come to see the beautiful sunrise and calm sea. Most of local people there are fishermen, owner of the small resorts and some working at the nearby Gebeng industrial area. The Kuantan port located 8 kilometers from Balok Baru, is a multi-cargo deep sea port that operating port everyday facing the South China Sea. The Kuantan port was constructed from year 1974 until 1976, was serve as expansion of industrial and manufacturing activities in East Coast Industrial Corridor. Other than that, the Royal Malaysian Navy (TLDM) also located about 9.7 kilometers away from Balok Baru is a naval base for Kuantan Navy [9].

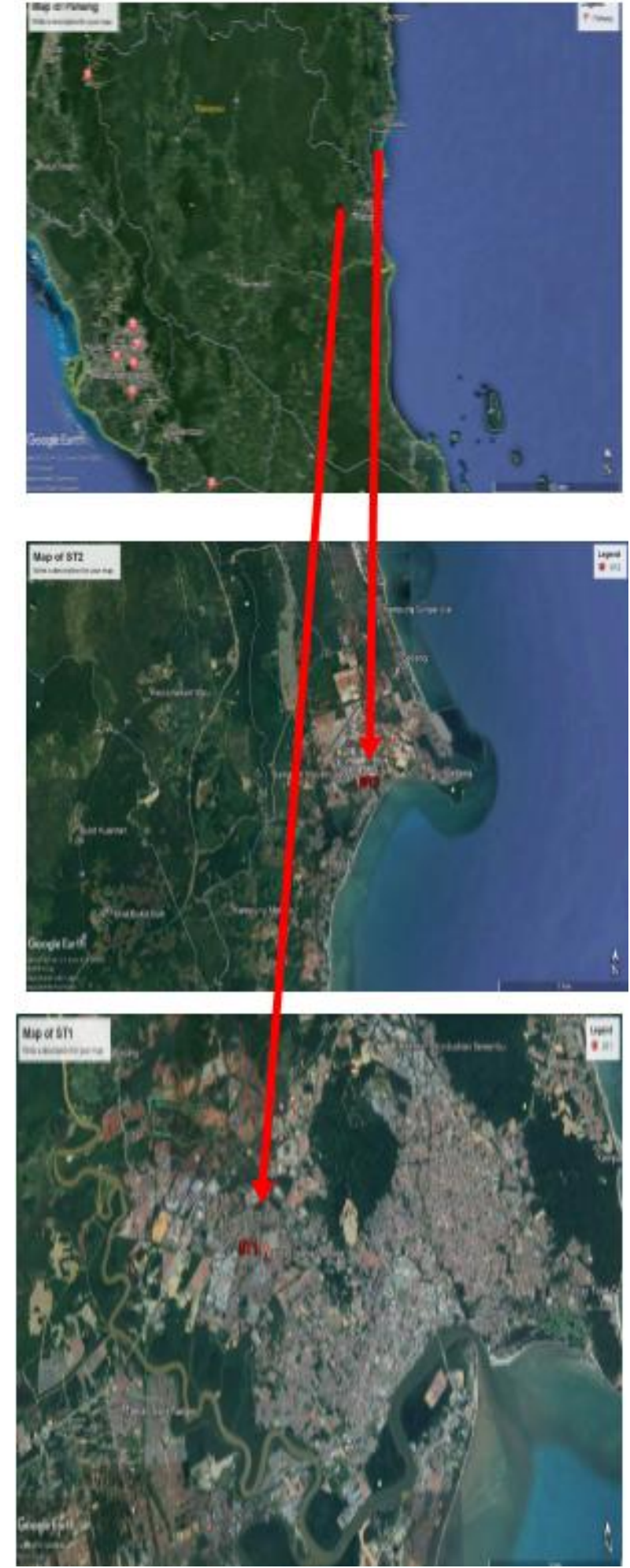

Fig. 1: Location of sampling station

\section{RESULTS AND DISCUSSION}

This section presents the concentration of PM10 for 15 years from year 2001 until 2016. Two station were involved in this study that are Station No.1 (ST1) Sekolah Kebangsaan Indera Mahkota, Kuantan dan Station No.2 (ST2) Sekolah Kebangsaan Balok Baru. The analysis showed the fluctuation graph of PM10 in 15 years duration 
time. For station No.1, three presentation graphs were determining its pattern concentration of PM10.

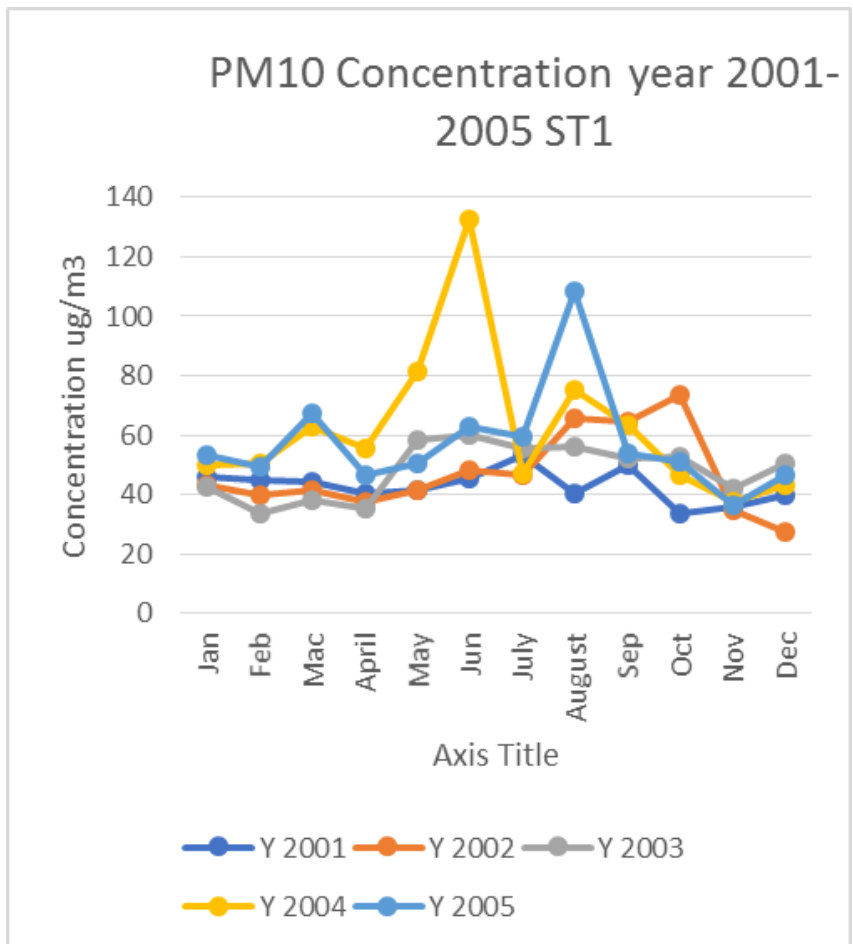

Fig. 2: Particulate Matter (PM10) from year 2001 until 2005 for Station 1

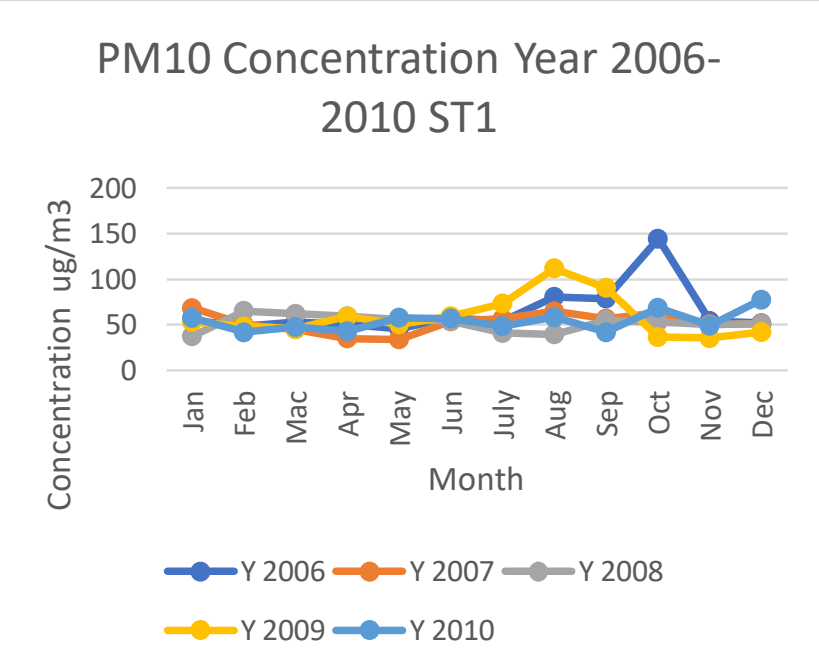

Fig. 3: Particulate Matter (PM10) from year 2006 until 2010 for Station 1

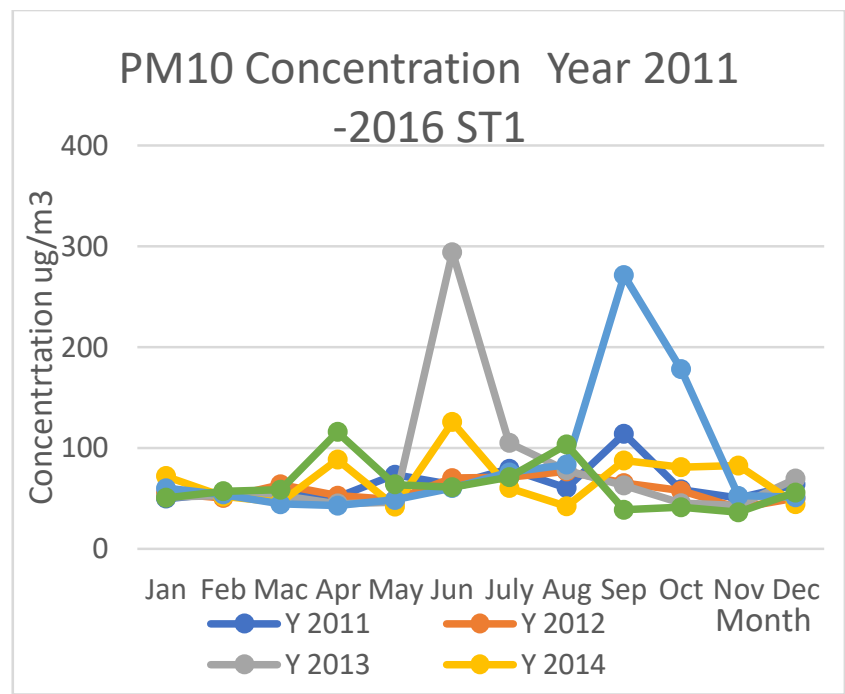

Fig. 4: Particulate Matter (PM10) from year 2011 until 2016 for Station 1

\section{PM10 CONCENTRATION YEAR 2001-2005 ST2}

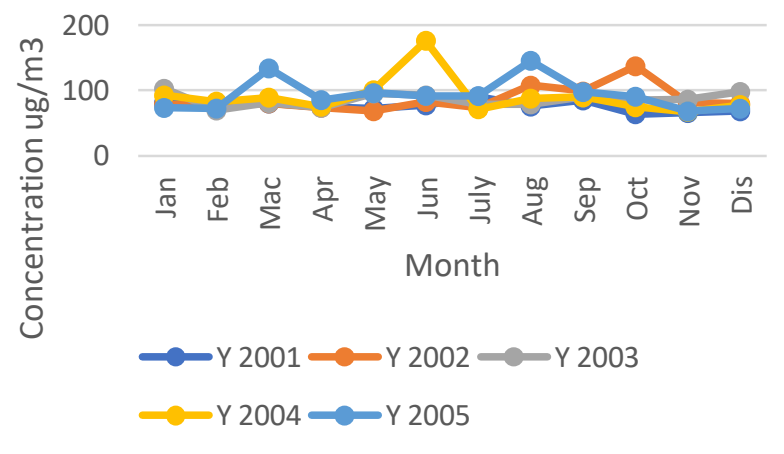

Fig. 5: Particulate Matter (PM10) from year 2001 until 2005 for Station 2

\section{PM10 CONCENTRATION YEAR 2006-2010 ST2}

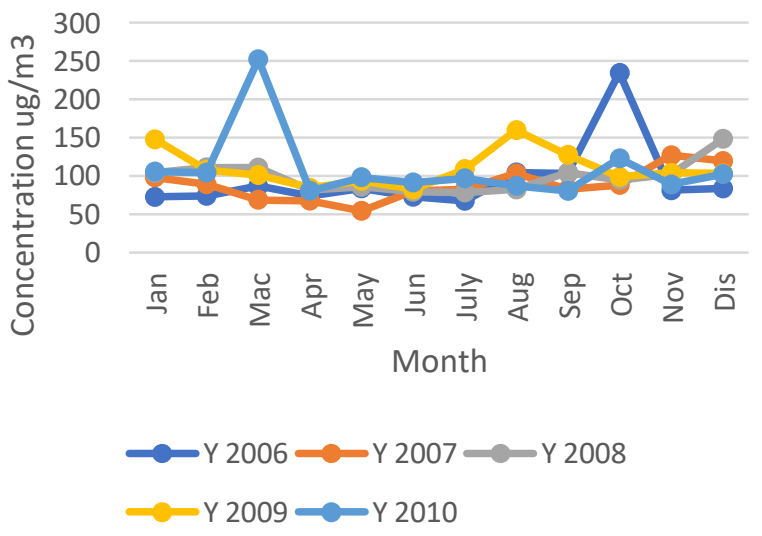

Fig. 6: Particulate Matter (PM10) for the year 2006 until 2010

Published By:

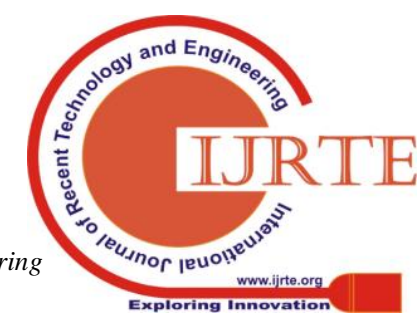




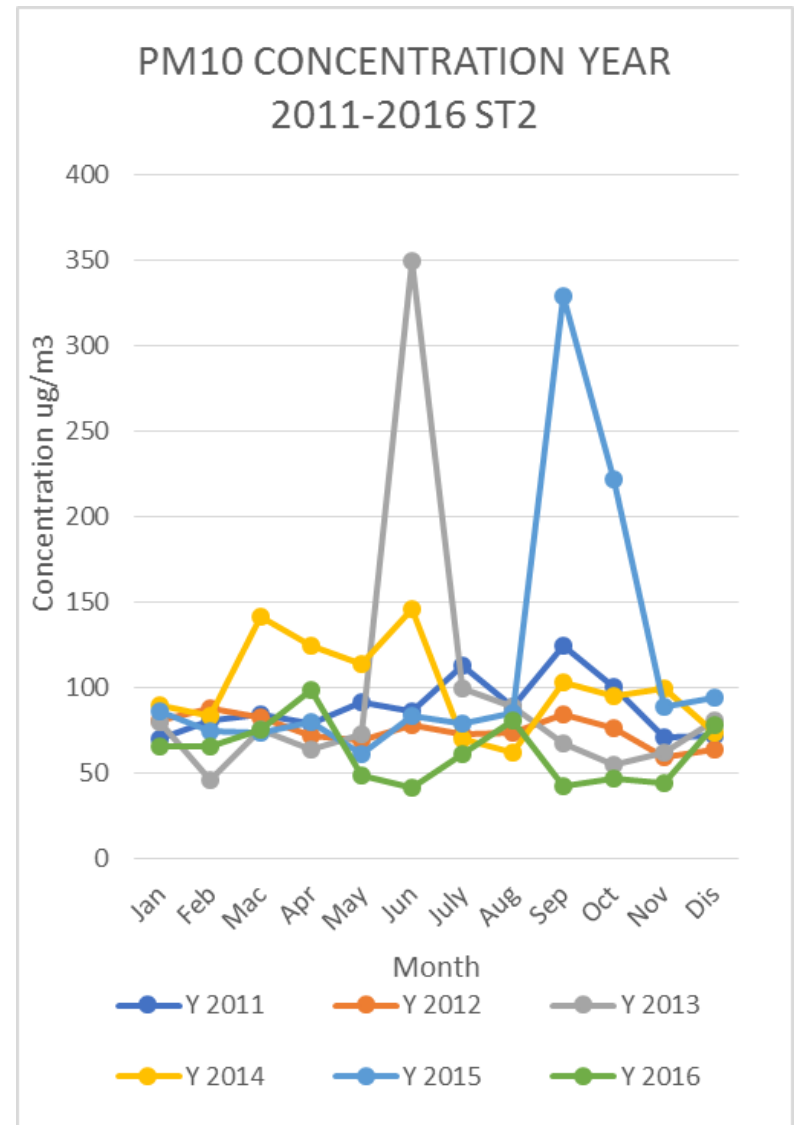

Fig. 7: Particulate Matter (PM10) for the year 2011 until 2016

\section{A. Particulate Matter Pattern Distribution at Station 1}

Analysis from the graph Fig. 2-4 from year 2001 until 2003, most concentration of PM10 are less than $80 \mathrm{ug} / \mathrm{m}^{3}$. But, starting May 2004 showed about $81.62 \mathrm{ug} / \mathrm{m}^{3}$ concentration of PM10 and it rose up to $132.8 \mathrm{ug} / \mathrm{m}^{3}$ in the next month. However, in month of July 2004 until July 2005 , the reading was less than $80 \mathrm{ug} / \mathrm{m}^{3}$. Yet, in month of August 2005, the concentration of PM10 shoot up to 108.47 $\mathrm{ug} / \mathrm{m}^{3}$ and started to decrease the next month.

The distribution of PM10 continues in year 2006 below $80 \mathrm{ug} / \mathrm{m}^{3}$ until the month of September, but increased drastically on the month of October with $144.35 \mathrm{ug} / \mathrm{m}^{3}$. From Nov 2006 until July 2009, the PM10 reading continuously below $80 \mathrm{ug} / \mathrm{m}^{3}$ and the concentration rocketed to $111.89 \mathrm{ug} / \mathrm{m}^{3}$ for the next month. However, the concentration started to decrease it reading in the month of September 2009 from $90.56 \mathrm{ug} / \mathrm{m}^{3}$ and continued less than $80 \mathrm{ug} / \mathrm{m}^{3}$.

In September 2011, the PM10 concentration showed $113.99 \mathrm{ug} / \mathrm{m}^{3}$ and declined on October until May 2013. But, the concentration PM10 increased drastically increased to $294.31 \mathrm{ug} / \mathrm{m}^{3}$ in the month of Jun 2013 and decrease to $105.02 \mathrm{ug} / \mathrm{m}^{3}$ on July 2013. The reading onwards was less than $80 \mathrm{ug} / \mathrm{m}^{3}$ until March 2014. The reading of PM10 were unstable on April, June, September, October and November with $88.42 \mathrm{ug} / \mathrm{m}^{3}, 125.77 \mathrm{ug} / \mathrm{m}^{3}, 87.45 \mathrm{ug} / \mathrm{m}^{3}, 80.87 \mathrm{ug} / \mathrm{m}^{3}$, and $82.41 \mathrm{ug} / \mathrm{m}^{3}$ respectively. Started from October 2015 the PM10 concentration increased fluctuated with 83.48 $\mathrm{ug} / \mathrm{m}^{3}, 271.64 \mathrm{ug} / \mathrm{m}^{3}$ and $178.27 \mathrm{ug} / \mathrm{m}^{3}$. In year 2016 were identified only two months that above $80 \mathrm{ug} / \mathrm{m}^{3}$ which in month of April with $115.96 \mathrm{ug} / \mathrm{m}^{3}$ and month of August with $103.41 \mathrm{ug} / \mathrm{m}^{3}$ respectively.

\section{B. Particulate Matter Pattern Distribution at Station 2}

The analysis station 2 for year 2001 until 2005, where in year 2001 the PM10 is slightly increased above $80 \mathrm{ug} / \mathrm{m} 3$ from the month of January, February and Mac with 81.47 $\mathrm{ug} / \mathrm{m} 3,81.88 \mathrm{ug} / \mathrm{m} 3$ and $80.3 \mathrm{ug} / \mathrm{m} 3$ respectively. However, the PM10 concentration slightly decreased below $80 \mathrm{ug} / \mathrm{m} 3$ in month of April, May and June. The PM10 showed increased for month of July and September with 90.79 $\mathrm{ug} / \mathrm{m} 3$ and $85.05 \mathrm{ug} / \mathrm{m} 3$. The rest of the month until the end of the year 2001, the PM10 is below than $80 \mathrm{ug} / \mathrm{m} 3$. In early year 2002, the PM10 showed below $80 \mathrm{ug} / \mathrm{m} 3$ but it slightly increased in the month of Mac with $80.5 \mathrm{ug} / \mathrm{m} 3$ but the concentration decreased again in month of April and May. However, from August until November 2002, the PM10 concentration showed PM10 concentration more than 50 $\mathrm{ug} / \mathrm{m} 3$ with the highest peak in October with $137.47 \mathrm{ug} / \mathrm{m} 3$. In year 2003, most of the months stated the concentration between $80 \mathrm{ug} / \mathrm{m} 3$ to $103 \mathrm{ug} / \mathrm{m} 3$ except the months of February, April, July and August. The PM10 concentration in the month of January, February and March of 2004 are $92.61 \mathrm{ug} / \mathrm{m} 3,83.26 \mathrm{ug} / \mathrm{m} 3$ and $89.36 \mathrm{ug} / \mathrm{m} 3$ respectively.

However, starting the month of May until September the concentration is above $80 \mathrm{ug} / \mathrm{m} 3$ with the highest concentration in June with $176.64 \mathrm{ug} / \mathrm{m} 3$. In year 2005, the PM10 concentration exceed more than $50 \mathrm{ug} / \mathrm{m} 3$ starting from the month of Mac until October with the highest concentration in the month of August with $145.86 \mathrm{ug} / \mathrm{m} 3$ follow by the month of Mac with $134.19 \mathrm{ug} / \mathrm{m} 3$. In year 2006, the graph PM10 concentration was fluctuating throughout the year and in month of October showed the highest PM10 concentration with $234.35 \mathrm{ug} / \mathrm{m} 3$. Yet, in year 2007, most of the PM10 concentration was not more than $120 \mathrm{ug} / \mathrm{m} 3$ expect in month of November the concentration was $126.64 \mathrm{ug} / \mathrm{m} 3$. The result PM10 concentration in year 2008, in month of February and Mac were slightly different with $110.97 \mathrm{ug} / \mathrm{m} 3$ and $110.6 \mathrm{ug} / \mathrm{m} 3$. From the month of September 2008 until the end year of 2010, the PM10 concentration were more than $80 \mathrm{ug} / \mathrm{m} 3$. The highest concentration was $252.16 \mathrm{ug} / \mathrm{m} 3$ in month of January 2010 follow by $159.6 \mathrm{ug} / \mathrm{m} 3$ in month of August 2009 and third, $127.33 \mathrm{ug} / \mathrm{m} 3$.

Fig. 7 showed that in year 2011, in month of February and Mac the PM10 concentration was $80.41 \mathrm{ug} / \mathrm{m} 3$ and 83.775 $\mathrm{ug} / \mathrm{m} 3$. But, in month of April the PM10 concentration slightly declined from $80 \mathrm{ug} / \mathrm{m} 3$ but from May until October the PM10 concentration above the $80 \mathrm{ug} / \mathrm{m} 3$ and it was fluctuating. The highest concentration was in month of September with $124.1 \mathrm{ug} / \mathrm{m} 3$, follow by month of July with $113.15 \mathrm{ug} / \mathrm{m} 3$ respectively. However, in month of 2012, the PM10 concentration was higher in the month of January until Mac with $80.67 \mathrm{ug} / \mathrm{m}^{3}, 67.47 \mathrm{ug} / \mathrm{m}^{3}$ and $82.09 \mathrm{ug} / \mathrm{m}^{3}$.

Throughout the month of 2012, the PM10 concentration was less than $80 \mathrm{ug} / \mathrm{m}^{3}$ except in month of September the PM10 concentration was $83.97 \mathrm{ug} / \mathrm{m}^{3}$. In year 2013, from 
month of February until May, the PM10 concentration was less than $80 \mathrm{ug} / \mathrm{m}^{3}$ but the PM10 concentration was rocketed in month of June with $349.7 \mathrm{ug} / \mathrm{m}^{3}$. The PM10 concentration decreased in the following month with $99.29 \mathrm{ug} / \mathrm{m}^{3}$ in July and $88.80 \mathrm{ug} / \mathrm{m}^{3}$ in August. Nevertheless, from December 2013 until June 2014, the PM concentration was above the $80 \mathrm{ug} / \mathrm{m}^{3}$ with the highest PM10 concentration was 145.96 $\mathrm{ug} / \mathrm{m}^{3}$ in June, follow by $141.14 \mathrm{ug} / \mathrm{m}^{3}$ in month of Mac and $124.51 \mathrm{ug} / \mathrm{m}^{3}$ in month of April. In month of September until November 2014 the PM10 concentration was slightly above $80 \mathrm{ug} / \mathrm{m}^{3}$. In year 2015 , the PM10 concentration again fluctuate in month of January with $86.11 \mathrm{ug} / \mathrm{m}^{3}$, month of June with $83 \mathrm{ug} / \mathrm{m}^{3}$ and $85.50 \mathrm{ug} / \mathrm{m}^{3}$ in month of August. However, the PM10 concentration showed the highest peak with $328.46 \mathrm{ug} / \mathrm{m}^{3}$ in month of September and slightly decreased with $221.31 \mathrm{ug} / \mathrm{m}^{3}$ in month of October. The continue months, the PM10 concentration was $89.05 \mathrm{ug} / \mathrm{m}^{3}$ and $93.62 \mathrm{ug} / \mathrm{m}^{3}$ respectively. In year 2016, only month of April and August, the PM10 concentration was $98.76 \mathrm{ug} / \mathrm{m}^{3}$ and $80.52 \mathrm{ug} / \mathrm{m}^{3}$ but the remains months the PM10 concentration was less than $80 \mathrm{ug} / \mathrm{m}^{3}$.

\section{Pattern Distribution Both ST1 and ST2}

Both station ST1 (Indera Mahkota) and ST2 (Balok Baru) showed the pattern distribution of PM10 concentration was above the 50ug/m3 according to Malaysia Ambient Air Quality Guidelines for 12 months. The impact of PM10 to Kuantan Citizen quite crucial. For ST1, the development around Indera Mahkota was missive in year until 2016. As the graph showed the highest peak of fficesPM10 on that particular year. More residentials, commercial and government building were built and access roads were constructed. Many areas were involved in build up a new town with many amenities, government offices and other hosing area. The road user that using the bypass to East Coast highway may contribute to the emission to the particular area.

For Balok Baru area, the development was higher starting form year 2005 until 2016. More residential area and open new Kuantan port cause the PM10 emission drastically. The development in Kuantan port was to turn into mega port for shipping hub for boosting Malaysia trade. The construction for industrial manufactures such as aluminum, steel, fertilizer, tires and ceramic sector will contribute the PM10 emission during the construction period. The land clearing activities causes more trees to be cut down and bare soil were exposed to erosion agent such as wind and rain. During the month of dry season, the wind causes the particulate matter to rise and distribute into the atmosphere.

The trans boundary movement of haze may contribute to the concentration emission. We can't control the haze episode due to its trans boundary that travel in our atmospheric that influences by wind. By controlling the land, a peat forest in Kuantan area, we might help to prevent peat fire form occur thus reduce the haze.

\section{CONCLUSION}

Because the Kuantan city need the development to become more suitable city to be lived by their citizen, more construction could take part in coming years, the local authority needs to plan strategy of construction period. By developing assessment, monitoring and early warning system and exchange information of technology would find better strategic planning for future development. The enforcement needs to take seriously to project proponent that responsible in developing the area, to reduce source emission at the site and comply with standard and regulation in Malaysia. Due to PM10 concentration for both monitoring station was more than $50 \mathrm{ug} / \mathrm{m}^{3}$, the mitigation and action to control emission of particulate matter (PM10) need to be done seriously and periodically monitor by the local authority. Hoping that the atmospheric of Kuantan City can be control and maintain its quality for better life.

\section{ACKNOWLEDGEMENT}

The author would like to thanks to Department of the Environment Malaysia for assistance with data sample and to Wikipedia, the free encyclopedia website, for Bandar Indera Mahkota and Balok Baru.

\section{REFERENCES}

1. S. A. Rahman, M. S. Hamzah, M. S. Elias, N. A. Salim, A. Hashim, S. Shukor, W. B. Siong, and A. K. Wood, "A long term study on characterization and source apportionment of particulate pollution in Klang Valley, Kuala Lumpur,' Aerosol and Air Quality Research, 15(6), 2015, pp. 2291-304.

2. Expert Panel on Air Quality Standards; Great Britain. Department of the Environment, Transport and the Regions; Scotland. Scottish Executive; Wales. National Assembly; Northern Ireland. Department of the Environment, Airborne particles: What is the appropriate measurement on which to base a standard? A discussion document. London: H.M.S.O., 2001.

3. G. M. Giavis, H. D. Kambezidis, and S. P. Lykoudis, "Frequency distribution of particulate matter (PM10) in urban environments," International Journal of Environment and Pollution, 36(1-3), 2008, pp. 99-109.

4. World Health Organization, WHO's ambient air pollution database - update 2014. Available: https://www.who.int/phe/health_topics/outdoorair/databases/ AAP_database_results_2014.pdf.

5. USEPA, Reviewing National Ambient Air Quality Standards (NAAQS): Particulate Matter (PM) Air Quality Standards. Available: https://www.epa.gov/naaqs/particulate-matter-pmair-quality-standards.

6. R. Bascom, P. A. Bromberg, D. L. Costa, R. Devlin, D. W Dockery, M. W. Frampton, W. Lambert, J. M. Samet, F. E. Speizer, and M. Utell, "Health effects of outdoor air pollution," American Journal of Respiratory and Critical Care Medicine, 153(2), 1996, pp. 477-498.

7. D. W. Dockery, C. A. Pope, X. Xu, J. D. Spengler, J. H. Ware, M. E. Fay, B. G. Ferris Jr, F. E. Speizer, "An association between air pollution and mortality in six US cities," New England Journal of Medicine, 329(24), 1993, pp. 1753-1759.

8. Wikipedia, Bandar Indera Mahkota. Available: https://en.wikipedia.org/wiki/Bandar_Indera_Mahkota.

9. Wikipedia, Kampung Baru. Available: https://ms.wikipedia.org/wiki/Kampung_Balok. 